\title{
The analysis of perceptions and attitudes related to ageing in the Federation of Bosnia and Herzegovina
}

\author{
VELMA PIJALOVIĆ, Ph.D.* \\ LEJLA LAZOVIĆ-PITA, Ph.D.* \\ ALMIR PEŠTEK, Ph.D.* \\ DANIJELA MARTINOVIĆ, Ph.D.*
}

Article**

JEL: H55, J14

https://doi.org/10.3326.pse.42.3.2

\footnotetext{
* The authors would like to thank the two independent reviewers for their most useful suggestions and comments. The article has not received any financial support

${ }^{* *}$ Received: May 15, 2018

Accepted: June 19, 2018
}

\author{
Velma PIJALOVIĆ \\ School of Economics and Business, University of Sarajevo, Trg oslobodjenja-Alija Izetbegovic 1, \\ 71000 Sarajevo, Bosnia and Herzegovina \\ e-mail: velma.tahmaz@efsa.unsa.ba \\ ORCiD: 0000-0002-9676-5408 \\ Lejla LAZOVIĆ-PITA \\ School of Economics and Business, University of Sarajevo, Trg oslobodjenja-Alija Izetbegovic 1, \\ 71000 Sarajevo, Bosnia and Herzegovina \\ e-mail: lejla.lazovic@efsa.unsa.ba \\ ORCiD: 0000-0001-9421-1842 \\ Almir PEŠTEK \\ School of Economics and Business, University of Sarajevo, Trg oslobodjenja-Alija Izetbegovic 1, \\ 71000 Sarajevo, Bosnia and Herzegovina \\ e-mail: almir.pestek@efsa.unsa.ba \\ ORCiD: 0000-0001-5958-4993 \\ Danijela MARTINOVIĆ \\ School of Economics and Business, University of Sarajevo, Trg oslobodjenja-Alija Izetbegovic 1, \\ 71000 Sarajevo, Bosnia and Herzegovina \\ e-mail: danijela.martinovic@efsa.unsa.ba \\ ORCiD: 0000-0002-6799-2265
}




\section{Abstract}

The problem of an ageing population has only recently gained attention in Bosnia and Herzegovina (BIH). Adequate pension reforms cannot be expected if most citizens are unaware of the issues or even oppose the reforms necessary. The primary research is based on opinion survey data collected in the Federation of Bosnia and Herzegovina (FBIH) with a special focus on the fact that the ageing of the population might pose a problem for pension systems in the future. The results show that more than three quarters of the respondents are aware of this problem in FBIH. The logit regression model shows that pensioners, respondents who prefer the primary role of government, those with higher levels of education and reported living standard are more likely to recognise this issue. Improvements in the efficiency of pension funds, reduction in public spending and active measures aimed at the prevention of emigration from BIH are the solutions most widely recognised.

Keywords: ageing population, pension reforms, survey, FBIH

\section{INTRODUCTION}

Demographic changes and the challenges of an ageing population are not a novelty in Europe. If Europe were divided into four geographic areas - Northern, Western, Eastern and Southern Europe (Population Reference Bureau, 2017), on average 20 per cent of all people in Northern and Southern Europe are 65 or older. This is an especially worrying fact in Southern Europe, to which BIH belongs. The BIH share of population older than 65 in total population in 2017 amounted to 16 per cent, which is below the Southern average, but is almost twice as high as the world average (9 per cent, Population Reference Bureau, 2017).

The socio-economic aspects of an ageing population are an issue that used to be associated only with rich countries (the OECD countries since the 1950s) since in those countries citizens were provided with high national incomes and better personal health. However, the most recent research from Lee, Mason and Cotlear (2010) indicates that developing and middle-income countries are facing a similar problem, largely without the economic means to cope with the social and economic challenges and hence an inability to adjust to this growing phenomenon. This phenomenon can be particularly seen in Southern and Eastern European countries to which BIH belongs (Cerami, 2008; 2010).

Recent economic issues and interventions associated with the so called Graying Revolution are attracting increasing interest and have been affecting several policy areas. Studies and research provided by international organisations such as the World Bank, the United Nations, the OECD and the European Commission deal with different aspects of policy areas related to the impact of the ageing population, in which the most common policy areas are health, pensions, long-term care services and employment policies. In this paper, the focus is on the pension system.

The purpose of the research is to analyse perceptions and attitudes of FBIH respondents in connection with the ageing population and possible associated 
problems. The research survey is based on Eurobarometer 56.1. Survey (Pension Policy and Pension reform 161/wave 56.1 in 2001). No such survey has been conducted in any of the Western Balkan countries or in BIH. The questions have been slightly adjusted to correspond to (F)BIH specifics and especially relate to the non- introduction of a three-pillar pension system in BIH.

Similar to recent research that deals with the phenomenon of ageing population, the first chapter provides a literature overview of the effect of the ageing population on pension systems in Southern and Eastern European countries. We highlight the fact that very little research has been done with respect to BIH in the past. The second chapter focuses on the analysis of demographic trends and the pension system in Bosnia and Herzegovina, primarily in the FBIH, providing an overview of the most recent pension reforms. In the first part of the final chapter a multilevel binomial logit regression on opinions of whether the ageing population will pose a problem has been developed. The results of the opinion survey conducted are analysed, together with the necessary proposals for possible solutions to this issue. Survey results correspond to the main findings of the situation in the pension systems of the developed countries and the Western Balkans, but certain peculiarities are also noted that indicate that "one size fits all" cannot be applied. The results should be included and evaluated in the future research and policy proposals in this area in $\mathrm{BIH}$.

\section{LITERATURE REVIEW}

The European Commission (EC) attempts to highlight the issue of an ageing population and its implications for economic and, specifically, the long term budgetary effects and projections in a document called the Annual Ageing Report. The current Report for 2018 is the sixth of the kind and it shows projections for each member state in terms of separate budgetary (expenditure) projections that are carried out for five government expenditure items (pensions, health care, longterm care, education and unemployment benefits). The report highlights the fact that within each policy the objectives and solutions cannot be of the "one size fits all" kind, but must be adjusted to the specific circumstances of each member state (European Commission, 2017). Since 2000, EU members have conducted a number of pension system reforms with a wide range of measures aimed at tackling the fiscal pressures caused by the ageing phenomenon. Holzmann, MacKellar and Repansek (2009) summarise the discussions related to the impacts that demographic challenges could have on public finances. Discussions relate to the drivers of necessary pensions reforms, the challenges countries have been facing (for example Augusztinovics, 1999; Fultz and Ruck, 2000; Bredenkamp, Gragnolati and Ramljak, 2008; Cerami, 2010; or Bloom et al., 2011) and possible solutions to this important issue focusing on changes in the labour market and financial market reforms as possible ways to resolve pension issues.

The relevance that ageing has on the pension system has been recognised for more than two decades. Authors such as Fischer and Reisen (1994), Hviding and Merette 
(1998) and Kohl and O'Brien (1998) analyse the effects that pension reforms have on accumulation of savings in public and private pension funds. Others, such as Roseveare et al. (1996), Verbič and Spruk (2014) or Žokalj (2016) evaluate the effects that pension policies have on public expenditures, budget deficits and public debt accumulation.

Most Central and South-Eastern European countries, except for BIH (Bartlett and Xhumari, 2007; Cerami, 2008, 2010; or Bartlett, 2012), have transformed their pension systems into three-pillar pension systems through the transition process. However, the introduction of the three-pillar pension system alone was usually not enough to solve the burning issues in the pension system and therefore most Central and South-Eastern European countries that are EU members have planned and conducted several other activities, especially since the outbreak of Global Financial Crisis of 2008-2009 (Guardiancich, 2013). Carone et al. (2016:7) provide a summary of pension measures in the EU since 1990s which have been decomposed in five broad categories: eligibility measures (e.g. pension ages, required contributory period), pension formula (e.g. definition of pensionable earnings, accrual rates, valorisation), indexation (calculation of the first pension in payment, and then the way it is valued over time), resources (e.g. social contributions, taxes) and schemes (merge or closure of pension schemes).

The most common measures relate to increasing retirement ages or reducing relative pension benefits. Central and South-Eastern EU member states have been applying a mix of measures within their three-pillar pension systems (public pension schemes, private occupational schemes and private individual schemes), where the final two include mandatory and voluntary status. Most have introduced mandatory private individual schemes (e.g. Bulgaria, Croatia, Hungary, Poland, Romania and Slovakia) and Slovenia adopted a mandatory private occupational scheme. Slovenia, a former Yugoslav country that inherited the Yugoslav PAYE pension system, was the first country within Yugoslavia that faced issues related to the ageing of the population and the need to reform the pension system. Authors such as Verbič, Majcen and Van Nieuwkoop (2006), Verbič (2007) and Verbič (2008) used a dynamic OLG general equilibrium model to provide an analysis of the ageing population in Slovenia and the associated challenges for the Slovenian pension system. Current research for the case of Slovenia (for example, OECD, 2015) further investigates the effects of demographic trends and the effects that ageing has on public finances as well as possible means of solving such issues.

In Central and South-Eastern EU member states, public pension schemes are all financed by the PAYE system and in Slovenia they are also pre-funded. In terms of types of pension applied, four options are available: flat-rate, defined benefits (DB), notional defined contributions (NDC) and points system (PS). Croatia, Romania and Slovakia converted their old DB public pillar to a points system (PS). An NDC system has been applied in some other Eastern European countries (such as Latvia and Poland). An important element is that the pre-funding of the new 
private pension schemes has often been financed through the reallocation of part of the social contributions - taxes raised for the statutory PAYE public scheme (Carone et al., 2016:16-17).

In terms of systematic reforms and progress in pension reforms, the EU tracks the implementation of mechanisms aimed at automatically adjusting key pension parameters to changes in life expectancy. These are: automatic balancing mechanisms that ensure that the pension system will be able to remain financially sustainable by adjusting benefits' indexation and/or by social contributions when needed, sustainability factors (i.e. a factor that changes the size of the pension benefit depending on the expected demographic changes, such as life expectancy at the time of retirement) and the automatic link between retirement ages and life expectancy. Very recently, Slovakia introduced the mechanism of linking the retirement age to life expectancy in 2012.

An interesting piece of research related to ageing problems by Bussolo, Koettl and Sinnott (2015) including 46 countries in Europe and Central Asia provides an analysis of policy challenges that ageing populations entail. Three main areas were included in the analysis: demography, economic consequences of an ageing population and the political economy challenge and then aggregated into eight indicators. The results are published in a country specific average indicator revealing a country's position and policy challenge in relation to other countries. The higher the indicator, the greater the policy challenge; countries were then grouped into four categories: young and adapting, young but lagging behind, old but adapting and old and lagging behind. BIH belongs among the Western Balkan countries, most of which are unfortunately in the last group. Countries such as BIH, Serbia and Montenegro together with Croatia (an EU member) are all presently facing this urgent problem and reforms are necessary (Koettl, 2016). For the case of $\mathrm{BIH}$, the indicator is the second largest of all the analysed 46 countries (right after Moldova) and followed by Albania and Serbia (Bussolo, Koettl and Sinnott, 2015:322-323). The Western Balkan countries are becoming old before they have developed the necessary economic and fiscal capacities to tackle this issue.

Lack of necessary resources has been recognised in the pension policy studies in Western Balkan countries. Most research for Western Balkan countries in the analysis of necessary pension reforms highlights the urgent need to reform such funds primarily due to the ageing of the population, and hence the financial instability of funds in the mid and long term. Authors such as Bošnjak (2016) for BIH; Stanić (2009) for Serbia; Shehi, Shahini and Dragoshi (2016) for Albania; Urban, Munđar and Bejaković (2011) or Nestić and Tomić (2012) for Croatia; and Bornarova, Bogoevska and Trbojevik (2013) for Macedonia have analysed the pension system and the challenges of an ageing population.

Research including opinion surveys concerning the effects that an ageing population has on a pension system was conducted in 2001 and results were presented in 
2004 for EU members (European Commission, 2004). The research examined the views of EU citizens about pension issues in the special Eurobarometer survey Pension Policy and Pension Reform 161/wave 56.1. Views were assessed across the $\mathrm{EU}$ and results were presented as aggregated at the level of $\mathrm{EU}$ and individual member states (European Commission, 2004). Authors such as Kohl (2003), Janky and Gál (2007) and Draxler and Mortensen (2009) either participated in the survey (Kohl, 2003) or used the results to assess the effects that an ageing population has on pension systems. No research including opinion surveys concerning the effects of an ageing population on the pension system in BIH has been conducted. Such research has not been conducted in any other Western Balkan country either. Hence, the research conducted could help policy makers in BIH in the creation of policy proposals.

\section{AGEING POPULATION AND PENSION REFORMS IN BIH}

The transition process and the expected speed of social reforms in BIH have both been very slow. As an unfortunate legacy of war in BIH (1992-1995) pension reforms and issues related to possible demographic challenges ahead have mostly been put aside. Additionally, lack of official data has postponed this process since official results of the Consensus from 2013 were officially published only in 2016, twenty-five years after the publication of the last Consensus in 1991. The war in $\mathrm{BIH}$ has left a drastic demographic legacy in BIH with a fall in the population from 4.3 million to the current 3.7 million. Under such circumstances and due to additional post-war pressures on social and health funds, BIH has faced additional problems. Table 1 provides a brief overview of the main macroeconomic and demographic indicators for BIH over the 1995-2016 period.

\section{TABLe 1}

Main macroeconomic and demographic indicators for BIH ${ }^{1}$, 1996-2016

\begin{tabular}{|c|c|c|c|c|}
\hline BIH & 1996 & 2002 & 2010 & 2016 \\
\hline GDP, per capita, current prices, US\$ & 983,1 & $1,753.1$ & $4,404.3$ & $4,298.4$ \\
\hline Inflation, $\%$ change & $\mathrm{n} / \mathrm{a}$ & -0.4 & 3.0 & -0.29 \\
\hline $\mathrm{U} / \mathrm{E}$ rate, $\%$ of labour force & 50.0 & 31.1 & 27.2 & 25.4 \\
\hline $\begin{array}{l}\text { General government total } \\
\text { expenditure, } \% \text { of GDP }\end{array}$ & $\mathrm{n} / \mathrm{a}$ & 47.6 & 49.5 & 43.0 \\
\hline $\begin{array}{l}\text { General government gross debt, } \\
\% \text { of GDP }\end{array}$ & $\mathrm{n} / \mathrm{a}$ & 31.2 & 42.7 & 44.7 \\
\hline $\begin{array}{l}\text { Population ages } 65 \text { and above, } \\
\% \text { of total population }\end{array}$ & 6.0 & 12.1 & 13.9 & 16.1 \\
\hline Pensioners/contributors ratio & 1988 & 2002 & 2010 & 2016 \\
\hline FBIH & \multirow{2}{*}{0.3} & 0.7 & 0.8 & 0.9 \\
\hline Republika Srpska (RS) & & 0.8 & 0.9 & 1.0 \\
\hline $\begin{array}{l}\text { Total public pension spending, } \\
\% \text { of GDP }\end{array}$ & $\ldots$ & $\ldots$ & $\begin{array}{c}6.5 \\
\left(2010, \mathrm{RS}^{\mathrm{a}}\right)\end{array}$ & $\begin{array}{c}9.4 \\
\left(\mathrm{BIH}, 2012^{\mathrm{a}}\right) \\
\end{array}$ \\
\hline
\end{tabular}

${ }^{a}$ Latest officially available data.

Source: FAS (1989); FBIH\&RS Statistics Office (2016); The World Bank (2016; 2017); IMF (2017).

${ }^{1}$ Brčko District is excluded from the analysis. 
Data presented in table 1 show a recovery in all macroeconomic indicators from 1996 until 2016 (except the rise in general government gross debt shown as a percentage of GDP until 2010). However, BIH, unlike any other transition country, entered the transition process war torn and with significant human and infrastructural losses, and it should therefore be noted that the starting point of all macroeconomic indicators was very low. For example, by 1995, BIH GDP ${ }^{2}$ had shrunk to less than a third of its pre-war level (World Bank, 1997:3). International aid for reconstruction and development speeded up the process in the first years of transition; however, migration and demographic changes made the social and mostly pension and health funds especially vulnerable. The share of total public pension spending as a percentage of GDP has increased from 3.3 per cent in 1996 (The World Bank, 1997) to 9.4 per cent in 2012.

Due to its specific post-war constitutional organisation, BIH has two pension funds (one in each BIH entity - FBIH and RS), which further hinders the implementation of an efficient pension policy. In FBIH, the necessity to reform the pension system was recognised some time ago, but has not been fully accomplished, and the FBIH still implements the PAYE system. As of 2013, more serious steps towards pension reforms have begun, so the government of FBIH published a proposal of the Pension System Reform Strategy in FBIH (FBIH Government, 2013). This document included the status and prospects of the pension system in the FBIH with suggestions for reform.

The document briefly analyses the demographic trends in FBIH in 2012 and expectations for the next twenty years considering the very low fertility (without migration at the end of projected period). Under such circumstances, it is expected that in FBIH, the share of population older than 65 years of age would grow to 25.2 per cent while the share of the young population (below the age of 15) would fall from 17.1 per cent to 11.7 percent (FBIH Government, 2013:9). As in almost all European countries, even with a slight increase in fertility rates, FBIH population will decrease in the next $40-50$ years by about 10 per cent and by an additional 11 per cent by 2073 (FBIH Government, 2013:9-10).

In terms of size and structure of pensions in $\mathrm{BIH}$, the analysis is conducted separately for the two $\mathrm{BIH}$ entities. Table 2 provides information regarding the share and the structure of pensions in both BIH entities for 2016.

Apart from the types of pensions provided in table 2, in FBIH, in terms of payment structure, there are four statutory (legal) groups of pension payments. Within each group, war veterans, different groups of armed forces/Ministry of Defence, members of the police and those who were militarily disabled, members of their families and other specific groups are eligible to receive pensions under special regulations in BIH. The Law on Service in the Armed Forces of Bosnia and Herzegovina provides detailed information related to old-age pensions and early retirement pensions under special conditions for these different groups.

\footnotetext{
${ }^{2}$ Bearing in mind that pre-war levels of GDP were expressed as GNP.
} 
TABLE 2

The size and the structure of monthly pensions in FBIH and RS for 2016 (in \%)

\begin{tabular}{|c|c|c|c|}
\hline $\begin{array}{l}\text { Pensions } \\
\text { in FBIH }\end{array}$ & $\begin{array}{c}\text { December 2016/ share } \\
\text { of beneficiaries }\end{array}$ & $\begin{array}{l}\text { Pensions } \\
\text { in RS }\end{array}$ & $\begin{array}{c}\text { December 2016/ } \\
\text { share of beneficiaries }\end{array}$ \\
\hline Old-age & 52.6 & Old-age & 54.9 \\
\hline Disability & 18.4 & Disability & 15.3 \\
\hline \multirow{2}{*}{ Family } & \multirow{2}{*}{29.0} & Family & 29.7 \\
\hline & & Other & 0.1 \\
\hline
\end{tabular}

Source: Federalni zavod PIO/MIO and Fond za penzijsko i invalidsko osiguranje Republike Srpske, 2016.

The highest share of paid-out pensions in both entities in 2016 was that of old-age pensions followed by family pensions. In fact, the situation in pension funds is very similar in both entities even though the FBIH had 401,335 beneficiaries and the RS 257,609 in 2016. The financial structure is similar to data presented in table 2. For example, approx. 58 per cent of all funds available in FBIH is paid out to old-age pensions, 16 per cent to disability and 25 per cent to family pensions (such data are not available for the RS). If we observe the period from 2010 until 2016 the share of old-age pensions has been increasing in both entities (from 45.9 per cent to the current 52.6 per cent in the FBIH and from 48.3 per cent to the current 54.9 per cent in the RS). We can assume a similar financial trend occurring in both entities. The average size of pensions in both entities is very low. In fact, average pensions in FBIH and RS in December 2016 amounted to 369 BAM (approx. 1893 EUR) and 342 (approx. 175 EUR) BAM respectively. From 2010 to 2016 average pensions have mostly been stagnating and the number of pension beneficiaries has been increasing.

Pension and disability insurance in the FBIH is regulated by law based on principles of reciprocity and intergenerational solidarity. This insurance includes: age, disability, death and physical disability caused by work. Pension rights deriving from these risks are the right to old age, disability and family pensions, and the right to financial compensation in the case of work-related physical incapacity. The pension fund in the FBIH is a social contributions fund and pension contributions are thus the main source of revenues. Apart from revenues from pension contributions, the law allows other payments such as contributions from voluntary insurance, self-employment, budget and other sources. Current pension contribution rates are 17 per cent and 6 per cent calculated on the gross wage and paid by employer and employee respectively.

The presented increase in the population aged 65 or older has more than doubled since the end of the war in BIH (table 1). Also, there is an increasing trend in the number of pensioners in FBIH, and this number has been rising by approx. 3.8 per cent per year on average (FBIH Government, 2013:12). The pensioners to con-

$\overline{{ }^{3} 1 \mathrm{EUR}}=1.95583 \mathrm{BAM}$ (fixed exchange rate). 
tributors' ratio has been deteriorating over the past thirty years in (F)BIH (table 1). Under the status quo in pension reforms, the projections of 2013 indicate that the ageing population and low activity rate will dominate the FBIH pension system. The number of pensioners is expected to increase by 2040, even at a faster rate if the abolition of the early retirement program is postponed. Still, this activity would be insufficient to mitigate unfavourable demographic trends. On the contributors' side, the number of insured persons is expected to continue to be affected by low activity rates, especially among women, significant emigration and high levels of grey economy. Hence, the pensioners to contributors' ratio in the FBIH is expected to reach 100 per cent by 2024 and a maximum of 146 per cent is expected by 2054 . By 2075, a fall in this ratio is expected (FBIH government, 2013:14).

The Reform Agenda for the period 2015-2018 in BIH highlighted the need to act fast in the pension system and pension funds. Due to the fact that pension reforms in the FBIH have been only slightly tackled in the past twenty years, this reform was assessed as necessary. In this sense, the new Law on Pension Insurance in the FBIH was enacted on the $1^{\text {st }}$ March 2018 and replaced the former FBIH Law on Pension and Disability Insurance passed twenty years ago. Even though this law brings new ways of solving long-term fiscal sustainability problems in the pension system, the PAYE system still prevails. Basic changes are related (but not limited) to:

a) Replacement of the DB system and introduction of the PS of pension calculation, whereby the amount of the pension would depend on the amount of the contributions paid.

b) The minimum age requirement for retirement is 65 years with a minimum of 15 years in service and minimum 20 years of paid pension insurance for both genders. In the prior law, the minimum age requirement for retirement was 65 years with a minimum 20 years of paid pension insurance.

c) Requirement for early old-age pension will change from year to year and will be significantly stricter than it was before. The requirement for early retirement in 2018 for men is 35.5 years of paid pension insurance and 60.5 years of life, while for women the condition is 30.5 years of paid pension insurance and 55.5 years of life. This limit will be shifted every year by half a year of life and half a year of paid pension insurance before reaching the 40-year limit of paid pension insurance.

d) A more rigorous set of penalties was introduced, which acts as a disincentive for early retirement ( 4 per cent annual reduction compared to prior 0.5 per cent reduction for each year below the necessary age limit of 65 years, Law on Pension and Disability Insurance, Official Gazette of FBIH no. 13/18).

In the first months after the adoption of the new law on pension insurance in FBIH, pension amounts increased (this increase covered 54,785 pensioners whose pensions increased by ten percent and 53,454 who received an increase of five percent); the deficit of the pension insurance fund was reduced and now stands at 103 million BAM. 


\subsection{SURVEY METHODOLOGY AND STRUCTURE OF THE SAMPLE}

The research design, including the questionnaire used in this empirical analysis, was principally developed on the basis of Eurobarometer survey, Pension Policy and Pension Reform 161/wave 56.1. In order to avoid possible misinterpretation, original questions from the Eurobarometer survey were translated into the local language and then translated back to English. Hence, the original questionnaire was only marginally modified and adopted to reflect FBIH specifics - such as legal and cultural characteristics, based on a pilot survey and comments and suggestions of two public sector experts. In addition to the standard set of socioeconomic background variables such as age, education, and income, the questionnaire included a set of questions related to the information and preferences about the current pension system, potential reform options as well as current self-reported lifestyle standard.

The data used in this analysis have been collected in February 2018. A self-administrated online survey was carried out using the exponential non-discriminative snowball sampling technique. The total sample size is 623 responses.

Frequency tests were conducted to provide descriptive information regarding variables, including demographics. The sample of respondents included more females than males and more respondents who are not retired (table 3). That the sample is predominantly composed of non-retired females is a consequence of the sampling method selected. However, as this research is at an initial stage of the exploration, the sample is considered relevant for the research aim, with no robustness.

In terms of respondents' level of education, the largest number of respondents have finished undergraduate studies (39.5 per cent) whereas 18 per cent of respondents have finished master studies. The youngest respondent in the sample was 20 years old and the oldest 92 years old. Most respondents (31.4 per cent) were in the 35-44 year-old cohort. Respondents were asked to estimate and report the average monthly net household income from all sources. Most respondents (27.1 per cent) reported that the monthly income of the household was above 2,500 BAM, while almost 4 per cent of the respondents stated that they live in the household where the net monthly income is 350 BAM or less. As a response to the subjective feeling of their living standard, out of the total of 599 respondents who answered this question, almost a half assessed their current standard of living as average. According to the data of the Federal Bureau of Statistics, the minimum pension in the FBIH in 2017 amounted to 326.17 BAM and the average net salary in the FBIH amounted to 888.00 BAM. 
TABLE 3

Sample description

\begin{tabular}{|c|c|c|}
\hline Factor & Category & $\%$ \\
\hline \multirow{2}{*}{ Status } & Not-Retired & 76.5 \\
\hline & Retired & 23.5 \\
\hline \multirow{2}{*}{ Gender } & Male & 39.4 \\
\hline & Female & 60.6 \\
\hline \multirow{6}{*}{ Age } & $15-24$ & 3.3 \\
\hline & $25-34$ & 16.2 \\
\hline & $35-44$ & 31.4 \\
\hline & $45-54$ & 16.2 \\
\hline & $55-64$ & 14.4 \\
\hline & $65+$ & 18.5 \\
\hline \multirow{8}{*}{ Education } & Without primary education & 0.3 \\
\hline & Primary education & 0.5 \\
\hline & Secondary education & 19.8 \\
\hline & Qualified worker & 2.7 \\
\hline & Short-cycle tertiary education & 9.8 \\
\hline & Bachelor or equivalent & 39.5 \\
\hline & Master or equivalent & 18.0 \\
\hline & Doctor or equivalent & 9.4 \\
\hline \multirow{7}{*}{$\begin{array}{l}\text { Self-reported net monthly } \\
\text { income }\end{array}$} & $350 \mathrm{BAM}$ or less & 3.9 \\
\hline & $351-700$ BAM & 11.6 \\
\hline & $701-1,000$ BAM & 12.2 \\
\hline & $1,001-1,500 \mathrm{BAM}$ & 16.3 \\
\hline & $1,501-2,000$ BAM & 16.1 \\
\hline & $2,001-2,500$ BAM & 12.8 \\
\hline & More than 2,500 BAM & 27.1 \\
\hline \multirow{7}{*}{ Self assessed standard of living } & Very poor & 1.0 \\
\hline & Poor & 1.5 \\
\hline & Just getting along & 12.7 \\
\hline & Average & 49.2 \\
\hline & Comfortable & 25.6 \\
\hline & Very comfortable & 9.6 \\
\hline & Rich & 0.4 \\
\hline
\end{tabular}

Source: Authors.

\subsection{WILL THE AGEING OF POPULATION POSE A PROBLEM FOR THE PENSION SYSTEM IN THE FUTURE? THE RESULTS OF LOGIT REGRESSION MODEL}

The responses related to the statement "The ageing population in our country will pose a problem for the pension system in the future" were assessed by using a five-point Likert-type scale (1 - "absolutely disagree", 2 - "disagree", 3 - "neither agree nor disagree", 4 - "agree", 5 - "absolutely agree"). Most respondents in the sample are aware of the problems caused by ageing population since 75.9 per cent responded positively to the former statement (32.5 per cent "agreed" and 43.4 per cent "absolutely agreed"). Only 4.8 per cent and 5.7 per cent of respondents absolutely disagreed or disagreed respectively while 13.6 per cent were neutral ("neither agreed nor disagreed"). 


\section{Figure 1}

Summary of responses to the statement: the ageing population in our country will pose a problem for the pension system in the future, number of respondents

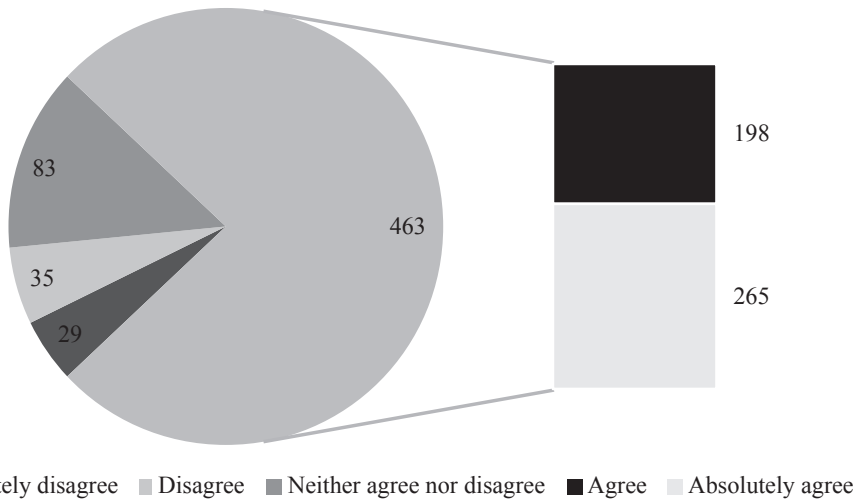

Source: Authors.

In order to separate the effects of the explanatory variables such as gender, age, income, education and standard of living on the attitudes towards the ageing population, logit regression analysis was conducted. The five-point Likert scale ${ }^{4}$ presented in the answers related to the statement that the ageing population would pose a problem for the pension system in the future was used in a variable as follows: answers 1 and 2 are summarised as "no" answers, answer 3 is "neutral" and it is not included in the analysis, and answers 4 and 5 are summarised as "yes" answers. Bearing in mind the former criteria, the size of the sample was reduced to 527 responses.

\section{TABle 4}

Regression coefficients of multilevel binomial logit regression on opinions of whether ageing population will pose a problem

Ageing population in our country will pose a problem for pension system in the future

\begin{tabular}{lc}
\hline Education & $.291^{*}$ \\
\hline Pensioners & $1.295^{*}$ \\
\hline Gender & .194 \\
\hline Age & -.321 \\
\hline Self-reported income & -.049 \\
\hline Role of government & $1.343^{* *}$ \\
\hline Living standard & $.734^{* *}$ \\
\hline Const. & -2.347 \\
\hline
\end{tabular}

${ }^{*} p<0.05,{ }^{* *} p<0.01$.

Source: Authors.

\footnotetext{
${ }^{4}$ The results from the Likert scale ( 1 to 5) were interpreted as follows: answers 1 and 2 are summarised as "I disagree", answer 3 is "neutral", and answers 4 and 5 as "I agree".
} 
Dependent variable is a response to the statement: "The ageing population in our country will pose a problem for the pension system in the future". It is a dichotomous variable whereby responses "I absolutely disagree" and "I disagree" were coded as zero (0), neutral responses were not considered and responses "I absolutely agree" and "I agree" were summarised as one (1).

Independent variables in this model are:

- Education: ordinal variable where "without primary education" was coded by "1"; "primary education" by " 2 "; "secondary education" by "3"; "qualified worker" by "4"; "short-cycle tertiary education" by "5"; "bachelor or equivalent" by "6"; "master or equivalent" by "7" and "doctoral or equivalent" by "8";

- Pensioners: dichotomous variable (zero or one) where retired respondents were coded by " 1 " and non-retired coded by " 0 ";

- Gender: dichotomous variable (zero or one) where male respondents were coded by " 1 " and women coded by " 0 ";

- Age: ordinal variable where 15-24-year-old coded by "1", 25-34 year-old = coded by " 2 ", 35-44 year-old coded by " 3 ", 45-54 year-old coded by "4", $55-64$ year-old coded by " 5 " and 65 or older coded by " 6 ";

- Self-reported income: ordinal variable where 350,00 BAM or less = "1", 351-700 BAM = "2", 701-1,000 BAM = "3", 1,001-1500 BAM = "4", 1,501$2,000 \mathrm{BAM}=$ " $5 ", 2,001-2,500 \mathrm{BAM}=$ " 6 " and more than 2,500 BAM = "7";

- Role of government: dichotomous variable (zero or one) as a response to the statement: "The state should be the most important participant in the economy" whereby responses "I absolutely disagree" and "I disagree" were coded as zero (0), neutral responses were not considered and responses "I absolutely agree" and "I agree" were coded as one (1);

- Standard of living: ordinal variable where "very poor" =1; "poor" = 2; "just getting along" $=3$; "average" $=4$; " comfortable" $=5$, "very comfortable" $=6$ and "rich" $=7$.

The regression results show that the retirees are more likely to see problems in demographic trends than respondents who are not retired. This is expected considering that the pensioners' living standard depends on the sustainability of the pension system. Respondents' financial situation is a very interesting factor shaping opinions; although household income does not affect their attitude to the problem of ageing, respondents with a high current self-reported living standard, who also pay more taxes, are more likely than others to see population ageing as a problem. Citizens who are better educated are also more likely to be aware of the problems of an ageing society. The difference is especially noticeable at lower levels of education. The results of the logit marginal effects analysis indicate that the likelihood that a person who has finished secondary education will see ageing as a problem is 1.36 times higher than for a person who has completed only primary education. Although other differences exist, they are less drastic for those who are more educated. Respondents who are in favour of a stronger role of government 
in the economy are more inclined to be aware of the ageing problem. A possible explanation for this lies in fact that those who believe that the state should be the main participant are more interested in the functioning and financing of the public sector in general, and the pension system in particular. Contrary to the expectations, the age variable was not significant, and therefore another model was developed with squared age but again, it was insignificant. Values of variance inflation factors (VIF) indicate that there are no serious problems with multicollinearity between the variables.

\subsection{ATTITUDES TOWARDS PROPOSALS FOR SOLVING THE AGEING POPULATION PROBLEM IN FBIH}

There are various proposals available to both government and private sector to deal with the ageing problem. Although the implementation of each of the proposals requires deeper economic, social and political analysis, knowledge of the respondents' attitudes can provide policymakers with an important insight into this issue. In the questionnaire, based on the Eurobarometer 161/wave 56.1, respondents were offered eleven proposals as statements on a five-point Likerttype scale, (responses were grouped as previously noted).

Eleven proposals could be grouped into:

- Three changes in parameters of pensions systems (raising the age of retirement, improving pension insurance funds, maintaining contribution rates).

- Three proposals related to increasing labour force participation (giving priority to fighting unemployment, improving integration of foreign workers, and reducing emigration).

- Two family policy proposals (giving financial support to families with more children and facilitating a reconciliation between the demands of work and family).

- Two proposals related to encouraging people to save part of their income for retirement age (providing financial tax incentives to encourage people to save more money and allowing people to invest their own contributions into private pension funds or life insurance of their choice).

- And a change in public expenditure as a way of reducing spending in other areas to make more money available for pensions.

Some of these changes require pension system reforms, others change in the labour market, migration policy or fiscal reforms. The results from the FBIH survey were compared to results published in the special Eurobarometer 161/wave 56.1 (The European Commission, 2004), but the interpretation requires special caution. Namely, results are only partly comparable because there is a large timespan between the two surveys and different surveys' sampling techniques have been used in the research (Eurobarometer included random sampling method while in $\mathrm{BIH}$, due to financial constraints, the exponential non-discriminative snowball sampling technique was used). 
A proposal related to increasing the retirement age is very often suggested as a way of solving the ageing population problem. However, it is also considered an economically and politically controversial proposal, which public opinion usually opposes. The research provided similar results where 72 per cent of respondents disagreed with the statement that "The age of retirement should be raised so that people work longer and therefore spend less time in retirement". This proposal is also unpopular among European citizens, where 69 per cent disagreed with the statement. Moreover, less than one third of respondents have a positive view of this issue in all of the member countries, except in Ireland where slightly more than 40 per cent of respondents agree with the proposal (European Commission, 2004:62). In the sample, 88 per cent of the respondents agreed with the statement that the problem of the ageing population should be solved by improving the efficiency of pension funds. This is expected, given the complex institutional structure of the pension system in the country. Respondents were indecisive when it comes to the issue of preventing the rise in contribution rates even if it means lower pension levels, since 34.7 per cent agreed with this statement and 35.3 per cent disagreed. In the EU, this opinion is supported by less than one third of respondents and disapproved of by a majority of citizens (more than fifty per cent of respondents). Furthermore, this proposal was not supported by more than 40 per cent of adult citizens in any of the member countries (European Commission, 2004:60). The number of people who are indecisive is relatively high in the FBIH (one quarter) and in the EU countries (16 per cent).

\section{Figure 2}

Attitudes towards changes in parameters of pensions systems (in \%)

The government should improve Pension Insurance fund

The age of retirement should be raised so that people work longer and therefore spend less time in retirement

Contribution rates should not be raised even if this means lower pension levels

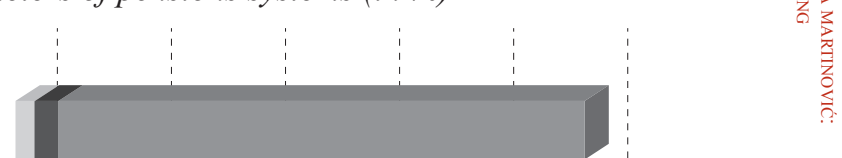

Source: Authors.

\subsubsection{Increasing labour force participation}

The situation in the labour market in (F)BIH is characterized by high unemployment (20.5 per cent in 2017, FBIH Statistics Office, 2016) with a very high youth 
unemployment rate, and in line with this 85 per cent of respondents agree with the statement that the government should give priority to fighting unemployment so that there will be more people who pay the taxes and contributions needed to finance pensions. Nevertheless, this proposal has received less support from the FBIH than from the EU citizens according to the results of the Eurobarometer survey, where 87 per cent of EU citizens were in favour of this proposal. In addition, general support for this strategy reached more than 80 per cent in all member states (European Commission, 2004:66). Although immigration of skilled labour is often proposed as a solution to the problems of the pension system caused by ageing, a larger number of FBIH respondents see the solution in implementing active policies to reduce the emigration of the population. Thus, the proposal that "more foreigners should be allowed to work in our country so that there will be more people who pay contributions and taxes needed to finance pensions" was strongly supported by more than one fifth of respondents and one third of respondents also agreed, so that more than fifty per cent in total had positive views. In comparison to the EU responses, where the total rate of agreement to this statement remained below 40 per cent, this proposal reached a high level of support among FBIH respondents. In fact, this statement revealed extreme cross-national differences among the EU members: while it was favoured by a majority of citizens in the Scandinavian countries (Sweden, Denmark and Finland), disapproval was the strongest in the United Kingdom, Belgium and France, with rates around 60 per cent (European Commission, 2004:70). It should be noted that the EU survey was conducted prior to the recent migration crisis so that the support data related to this policy would probably be very different nowadays. Unlike some European countries, $\mathrm{BIH}$ has not yet faced migrant problems, and the explanation for a greater support to reducing emigration ( 88 per cent) than for increase of immigration of foreign workers (52 per cent) can be sought in the emigration trend in the past few years, not in an anti-migrant mood.

\section{Figure 3}

Attitudes towards increasing labour force participation (in \%)

More foreigners should be allowed to work in our country so that there will be more people who pay the contributions and taxes needed to finance pensions

The government should implement active policies to reduce the emigration of the population from BIH

The government should give priority to fighting unemployment so that there will be more people who pay taxes and contributions needed to finance pensions
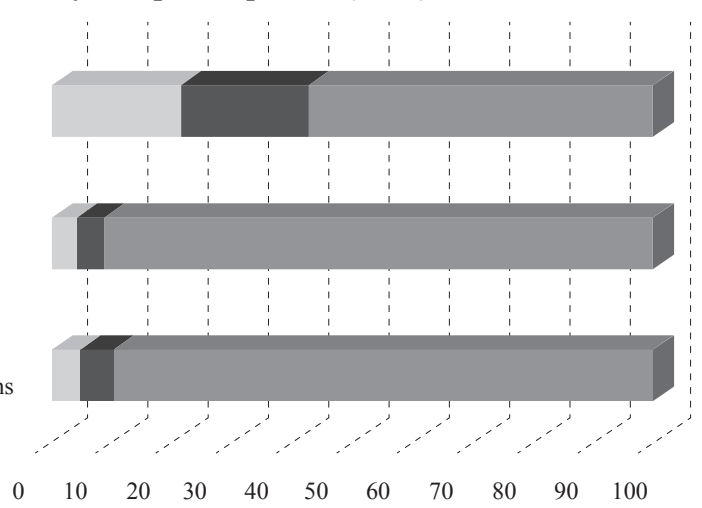

I disagree $\quad$ Neutral I agree

Source: Authors. 


\subsubsection{Attitudes towards family policies}

The key family-related policy instruments are aimed at trying to accommodate work and family life especially for women and to provide support for people who want to have more children. According to the data from the Labour Force Survey for BIH in 2017, women account for almost 40 per cent of the total labour force, which indicates the presence of gender inequality. The respondents are aware of this problem since more than 80 per cent support improving the position of women in the labour market and increasing birth rates through giving support to people with more children. The proposal that the government should make it easier especially for women - to combine family and work and thereby attempt to increase the number of women in employment was supported by 81 per cent of respondents and the proposal that "the government should give greater support to people who want to have more children" by 84 per cent of respondents. Increasing the labour force participation of women is also a widely supported proposal in the EU since more than 80 per cent agreed with this proposal. The support was especially strong in Greece ( 94 per cent), Spain, Portugal and Ireland (89 per cent 82 per cent respectively) where women's employment rate has been traditionally low so far, but also in Sweden (88 per cent) and Denmark (86 per cent) - countries with the highest rates of female employment (The European Commission, 2004:68).

\section{Figure 4}

Attitudes towards family policy (in \%)

The government should give more support to people who want to have more children

The government should make it easier - especially for women - to combine family and business and thus try to increase the number of employed women

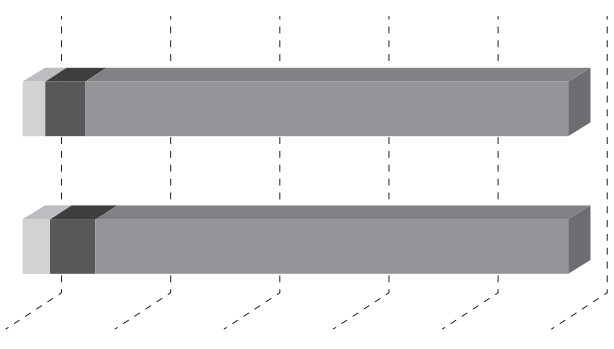

$\begin{array}{ccccccc} & 0 & 20 & 40 & 60 & 80 & 100 \\ \text { I I disagree } & \text { Neutral } & \text { I agree } & & \end{array}$

Source: Authors.

\subsubsection{Encouraging people to save part of their income for retirement age}

Considering the very low standard of living of retired persons in the FBIH, it is not surprising that respondents strongly support the proposal that encourages people to save a part of their income for retirement. Hence, the proposal that "the government should provide financial tax incentives to encourage people to save/make private provisions for their retirement" gained support by 81 per cent of respondents and only six per cent disagreed with proposal. In the context of FBIH with PAYE system, where three pillars of pension insurance have not been implemented, it is interesting to look at the answers of respondents related to private pension funds and life insurance as alternatives to pensions. The proposal that "the govern- 
ment should allow people to put their contributions into private pension funds or life insurance policies of their choice" was endorsed by more than three quarters or respondents.

\section{FiguRe 5}

Attitudes towards encouraging people to save part of their income to retirement age (in \%)

The government should allow people to invest their own contributions into private pension funds or life insurance of their choice

The government should provide financial tax incentives to encourage people to save money for retirement
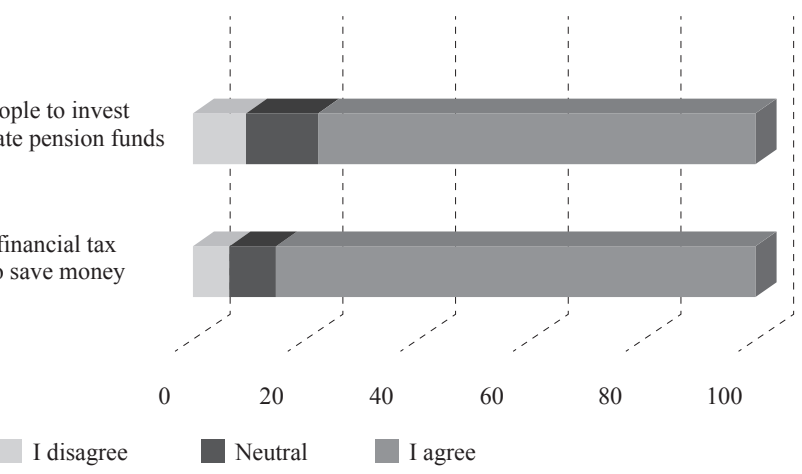

Source: Authors.

\subsubsection{Changes in public expenditures}

Considering the high levels of public spending in $\mathrm{BIH}$, expressed as a share of public expenditures to GDP (table 1) it is expected that 83 per cent of respondents in FBIH think that the government should cut spending in other areas in order to make more money available for pensions. In the EU slightly more than three quarters of respondents agreed with this proposal whereas the Portuguese and Greeks agreed the most with 90 per cent respondents supporting this measure. In four countries (United Kingdom, Sweden, Finland and Denmark) one quarter of respondents disagree with this change in public spending (European Commission, 2004:63).

\section{Figure 6}

Attitudes towards changes in public expenditure structure (in \%)

The government should reduce spending in other areas in order to make more money available for pensions

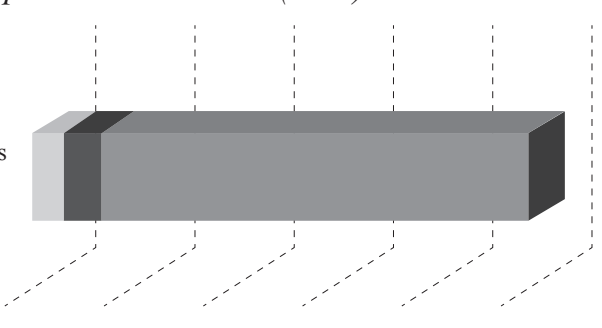


The share of persons aged 65 and older in total population is increasingly becoming a problem in European countries, including BIH. Since the end of the war in $\mathrm{BIH}$, the share of persons aged 65 and older in total population has risen from 6 per cent to more than 16 per cent. This trend causes many changes, where the most important ones are related to the pension system, health system and labour market.

The problems of ageing in BIH put additional pressures on the fiscally unsustainable pension system in $\mathrm{BIH}$, and the policy makers have in the past few years recognised this issue, which led to the adoption of the Reform Agenda for the period 2015-2018. The Reform Agenda resulted in a new Law on Pension and Disability Insurance in FBIH in 2018. The growing problem of the ageing population was also recognised in the primary survey conducted in FBIH, where 75.9 percent of all respondents believed that the ageing population in our country would pose a problem for the pension system in the future. The results from the logit regression model indicate that pensioners and respondents with higher levels of education are more likely to support this statement than those who are not retired and those who have less formal education. Furthermore, those who believe that the government should have the primary role in the economy and those who have reported a better standard of living are also more inclined to answer positively to the statement related to the problems of the ageing population in the pension system in the future.

In order to determine the attitudes of respondents toward possible solutions, eleven proposals were provided and grouped into five related policy areas. Within changes in the parameters of the pensions system, respondents agreed on the statement related to improving pension insurance funds, disagreed on the statement related to raising the age of retirement and were indecisive about maintaining contribution rates even if it meant lower pensions. Respondents agreed to all the statements related to increasing labour force participation (giving priority to fighting unemployment, improving integration of foreign workers, and reducing emigration) as well as family policy (giving financial support to families with more children and facilitating a reconciliation between the demands of work and of family). Encouragement of savings for retirement age in terms of financial tax incentives and private pension funds also elicited a positive response, together with public expenditure policies in terms of reduction of public spending.

Although the analysis carried out in the FBIH provides policy makers with an insight into the attitudes and perceptions of the public regarding the implementation of measures aimed at addressing the problem of an ageing population, this is a question that requires further analysis and further research into the impact that ageing population has on pension systems. The main limitation of the survey conducted relates to the sampling method and geographical coverage. Field research covering the whole of BIH was constrained for financial reasons so the next ques- 
tionnaire should include fieldwork and a random sampling method similar to Eurobarometer practice.

\section{Disclosure statement}

All authors state that they do not have any financial or other substantive conflict of interest. 


\section{REFERENCES}

1. Augusztinovics, M., 1999. Pension Systems and Reforms in the Transition Countries. Economic Survey of Europe, (3), pp. 89-114. Available at: $<$ https:// www.unece.org/fileadmin/DAM/ead/pub/993/993_4.pdf>

2. Bartlett, W. and Xhumari, M., 2007. Social Security Policy and Pension Reforms in the Western Balkans. European Journal of Social Security, 9(4). https://doi.org/10.1177/138826270700900401

3. Bartlett, W., 2012. The Political Economy of Welfare Reform in the Western Balkans in: C. Laderch and S. Savastano, eds. Poverty and Exclusion in the Western Balkans: New Dimensions for Measuring Poverty, pp. 245-259. Berlin: Springer.

4. Bloom, D. E. [et al.], 2011. Population Aging: Facts, Challenges, and Responses. PGDA Working Paper, No. 71. Available at: <https://www.aarp.org/content/ dam/aarp/livable-communities/old-learn/demographics/population-.agingfacts-challenges-and-responses-2011-aarp.pdf>

5. Bornarova, S., Bogoevska, N. and Trbojevik, S., 2013. Pension System Reforms in the Republic of Macedonia: Expected Benefits and Challenges. Academic Journal of Interdisciplinary Studies, 2(9), pp. 393-399. https://doi.org/10.5901/ ajis.2013.v2n9p393

6. Bošnjak, N., 2016. The pension system of Bosnia and Hezegovina: the problems and perspectives. European Journal of Multidisciplinary studies, 1(2), pp. 186-194. Available at: <http://journals.euser.org/files/articles/ejms_jan apr_16_nr2/Nikolina.pdf>

7. Bredenkamp, C., Gragnolati, M. and Ramljak, V. (eds.), 2008. Enhancing Efficiency and Equity: Challenges and Reform Opportunities Facing Health and Pension Systems in the Western Balkans. Health, Nutrition and Population (HNP) Discussion Paper, No. 46706. Available at: <http://documents. worldbank.org/curated/en/455751468101062450/pdf/467060WP0Box331ing Efficiency1Equity.pdf $>$

8. Bussolo, M., Koettl, J. and Sinnott, E., 2015. Golden aging - Prospects for Healthy, Active, and Prosperous Aging in Europe and Central Asia. The World Bank group. Available at: $<$ http://www.worldbank.org/en/region/eca/publication/golden-aging>

9. Carone, G. [et al.], 2016. Pension Reforms in the EU since the Early 2000's: Achievements and Challenges Ahead. European Economy Discussion paper, No. 42. http://dx.doi.org/10.2765/620267

10. Cerami, A., 2008. New Social Risks in Central and Eastern Europe: The Need for a New Empowering Politics of the Welfare State. Czech Sociological Review, (44), pp. 1089-1110. Available at: $<$ http://sreview.soc.cas.cz/uploads/ec66cf76acc90e6d7c1d0042ec87a964782e9883_511_Ceramisoccas2008-6.pdf>

11. Cerami, A., 2010. Ageing and the politics of pension reforms in Central Europe, South-Eastern Europe and the Baltic States. International Journal of Social Welfare, 20(4), pp. 331-343. https://doi.org/10.1111/j.1468-2397.2010.00748.x 
12. Draxler, J. and Mortensen, J., 2009. Towards Sustainable but Still Adequate Pensions in the EU Theory, Trends and Simulations. Enepri Research Report, No. 67. Available at: <http://aei.pitt.edu/14690/1/1836.pdf $>$

13. European Commission, 2004. The Future of Pension Systems. Special Eurobarometer, No. 161. Available at: <https://www.europeandataportal.eu/data/ en/dataset/http-ec-europa-eu-public_opinion-archives-eb_special_180_160_ en-htm161>

14. European Commission, 2017. The 2018 Ageing Report - Underlying Assumptions \& Projection Methodologies. Institutional Paper, No. 65. Available at: <https://ec.europa.eu/info/sites/info/files/economy-finance/ip065_en.pdf>

15. FAS, 1989. Statistical Yearbook of Yugoslavia. No. 36. Belgrade: Federal Agency of Statistics.

16. FBIH Government, 2013. Strategija reforme penzijskog sistema u Federaciji Bosne i Hercegovine (prijedlog). Sarajevo: Predstavnički Dom Parlamenta FBIH.

17. FBIH Statistics Office, 2016. Statistički godišnjak. Sarajevo: Federalni zavod za statistiku.

18. Fischer, H. and Reisen, B., 1994. Pension Fund Investment from Ageing to Emerging Markets. OECD Development centre. Policy brief, No. 9.

19. Federalni zavod PIO/MIO, 2016. Structure of pensions. Available at: $<$ http:// www.fzmiopio.ba/index.php?option $=$ com_content $\& v i e w=$ article $\& i d=65 \&$ Ite mid $=68 \&$ lang $=$ ba $>$

20. Fond za penzijsko i invalidsko osiguranje Republike Srpske. 2016. Structure of pensions. Available at: <http://www.fondpiors.org/>

21. Fultz, E. and Ruck, M. 2000. Pension reform in Central and Eastern Europe: An Update on the Restructuring of National Pension Schemes in Selected Countries. Budapest: ILO, Central and Eastern European Team Budapest.

22. Guardiancich, I., 2013. Pension Reforms in Central, Eastern and Southeastern Europe: From post-socialist transition to the global financial crisis. London; New York: Routledge.

23. Holzmann, R., MacKellar, L. and Repansek, J., 2009. Pension Reform in Southeastern Europe: Linking to Labor and Financial Market Reforms. Washington: The World Bank.

24. Hviding, K. and Merette, M., 1998. Macroeconomic effects of pension reforms in the context of ageing populations: overlapping generations model simulations for seven OECD countries. OECD Economics department working papers, No. 201. https://doi.org/10.1787/638376177076

25. IMF, 2017. International Monetary Fund. World Economic Outlook Database. Washington: International Monetary Fund. Available at: $<$ https://www. imf.org/external/pubs/ft/weo/2017/02/weodata/index.aspx>

26. Janky, B. and Gál, I. R., 2007. Public Opinion on Pension Systems in Europe. ENEPRI Research Report, No. 36. Available at: <http://aei.pitt.edu/9468/2/ 9468.pdf> 
27. Koettl, J., 2016. Which countries face the biggest policy challenges of aging populations in Europe and Central Asia? Eurasian perspectives, October 13, 2016. Available at: <http://blogs.worldbank.org/europeandcentralasia/whichcountries-face-biggest-policy-challenges-aging-populations-europe-and-central-asia $>$

28. Kohl, J., 2003. Principles of Distributive Justice in Pension Policies: CrossNational Variations in Public Opinion. Paper prepared for the Conference "New Challenges for Welfare State Research" in Toronto, August 21-24.

29. Kohl, R. and O`Brien, P., 1998. The Macroeconomics of Ageing, Pensions and Savings: A Survey. OECD Economics Department Working Papers, No. 200. Available at: <http://www.vwl.tuwien.ac.at/hanappi/AgeSo/SecReps/awp1_1e. pdf $>$

30. Law on pension and disability insurance. Official gazette of FBIH, No. 29/98, 49/00 and 32/01, 73/05, 59/06, 4/09.

31. Law on pension and disability insurance. Official gazette of FBIH, No. 13/18.

32. Law on Service in the Armed Forces of Bosnia and Herzegovina. Official Gazette of BiH, No. 88/05, 53/07, 59/09, 74/10 and 42/12.

33. Lee, R., Mason, A. and Cotlear, D., 2010. Some Economic Consequences of Global Aging - A Discussion Note for the World Bank. HNP Discussion Paper. Available at: <http://siteresources.worldbank.org/HEALTHNUTRITIONANDPOPULATION/Resources/281627-1095698140167/SomeEconomicConsequencesOfGlobalAging.pdf $>$

34. Nestić, D. and Tomić, I., 2012. Primjerenost mirovina u Hrvatskoj: što mogu očekivati budući umirovljenici? Privredna kretanja i ekonomska politika, 130.

35. OECD, 2015. Economic Survey of Slovenia 2017. OECD: Paris. Available at: <www.oecd.org/eco/surveys/economic-survey-slovenia.htm>

36. Population Reference Bureau, 2017. 2017 World Population Data - International indicators. Available at: <https://www.prb.org/international/>

37. Roseveare, D. [et al.], 1996. Ageing Populations, Pension systems and government budgets: simulations for 20 OECD countries. OECD economics department working papers, No. 168. https://doi.org/10.1787/463240307711

38. RS Statistics Office, 2016. Statistički godišnjak. Available at: <www.rzs.rs.ba>

39. Shehi, E., Shahini, L. and Dragoshi, G., 2016. Private pension system in Albania. Quantitative Methods in Economics, 17(4), pp. 138-148. https://doi. org/10.22630/MIBE.2016.17.4.12

40. Stanić, K., 2009. Penzijski sistem u Srbiji-dizajn, karakteristike i preporuke. Belgrade: Centar za liberalno-demokratske studije.

41. Urban, I., Munđar, D. and Bejaković, P., 2011. Mirovinski sustavi preraspodjela dohotka - predstavljanje istraživanja. Zagreb: Institut za javne financije.

42. Verbič, M., 2007. Varying the parameters of the Slovenian pension system: an analysis with an overlapping-generations general equilibrium model. Post-communist economies, 19(4), pp. 449-470. https://doi.org/10.1080/ 14631370701680154 
43. Verbič, M., 2008. The Ageing Population and the Associated Challenges of the Slovenian Pension System. Financial theory and practice, 32(3), pp. 321-338. Available at: <http://www.fintp.hr/upload/files/ftp/2008/3/verbic.pdf>

44. Verbič, M. and Spruk, R. 2014. Aging Population and Public Pensions: Theory and Macroeconometric Evidence. Panoeconomicus, 61(3), pp. 289-316. https://doi.org/10.2298/PAN1403289V

45. Verbič, M., Majcen, B. and van Nieuwkoop, R., 2006. Sustainability of the Slovenian pension system: an analysis with an overlapping-generations general equilibrium model. Eastern European Economics, 44(4), pp. 60-81. https://doi.org/10.2753/EEE0012-8775440403

46. World Bank, 1997. Bosnia and Herzegovina - From Recovery to Sustainable Growth (Country Study). Washington: The World Bank.

47. World Bank, 2016. Pensions Database GP Social Protection Q42016. Washington: The World Bank. Available at: <http://www.worldbank.org/en/topic/ socialprotection/brief/pensions-data>

48. World Bank, 2017. Population ages 65 and above (\% of total). Washington: The World Bank. Available at: >https://data.worldbank.org/indicator/ SP.POP.65UP.TO.ZS>

49. Žokalj, M., 2016. The impact of population aging on public finance in the European Union. Financial Theory and Practice, 40(4), pp. 383-412. https:// doi.org/10.3326/fintp.40.4.2 